\title{
Dissipation characteristics of mandipropamid and thiamethoxam for establishment of pre-harvest residue limits in lettuce
}

\author{
Seung-Hyun Yang ${ }^{1}$ (D) Jae-In Lee ${ }^{1,2}$ (D) $\cdot$ Hoon Choi ${ }^{1}$
}

\section{상추의 생산단계 잔류허용기준 설정을 위한 농약 Mandipropamid 및 Thiamethoxam의 잔류소실특성 연구}

\author{
양숭현 ${ }^{1} \cdot$ 이재인 ${ }^{1,2} \cdot$ 최 훈 ${ }^{1}$
}

Received: 21 August 2020 / Accepted: 16 September 2020 / Published Online: 30 September 2020

(C) The Korean Society for Applied Biological Chemistry 2020

\begin{abstract}
The dissipation characteristics and kinetics of fungicide mandipropamid and insecticide thiamethoxam in lettuce under greenhouse conditions were investigated at three different lettucegrowing fields for estimating the pre-harvest residue limits (PHRLs). The analytical methods were fully validated for the quantitation of pesticide residues using High-Performance Liquid Chromatography-Photo Diode Array detector or UltravioletVisible Detector and applied to real samples. The lettuces suitable for shipment were harvested during 10 days including pre-harvest interval after treatment at the recommended dose by safe-use guidelines. The initial mean residues in different fields were 6.6817.87 and $4.96-8.31 \mathrm{mg} / \mathrm{kg}$ for mandipropamid and thiamethoxam, respectively, which decreased to $16-54$ and $14-44 \%$ in 10 days. The clothianidin, a metabolite of thiamethoxam, was detected in $<0.02$ to $0.37 \mathrm{mg} / \mathrm{kg}$. The dissipation of both pesticides followed first-order kinetics over a period of 10 days after application. Based on the residue data, the mean dissipation rate constant $(\lambda)$ and biological half-lives $\left(T_{1 / 2}\right)$ were estimated to be -0.1060 and
\end{abstract}

Hoon Choi $(\triangle)$

E-mail: hchoi0314@wku.ac.kr

${ }^{1}$ Department of Bio-Environmental Chemistry, College of Agriculture and Food Sciences, Wonkwang University, Iksan 54538, Republic of Korea

${ }^{2}$ DongBang Agro Corporation, Buyeo 33216, Republic of Korea

This is an Open Access article distributed under the terms of the Creative Commons Attribution Non-Commercial License (http://creativecommons. org/licenses/by-nc/3.0/) which permits unrestricted non-commercial use, distribution, and reproduction in any medium, provided the original work is properly cited.
6.5 days of mandipropamid and -0.1236 and 5.6 days of thiamethoxam. The PHRLs for lettuce on the 10th and 5th day before harvesting were calculated to be 63.24 and $43.56 \mathrm{mg} / \mathrm{kg}$ for mandipropamid, and 44.66 and $25.88 \mathrm{mg} / \mathrm{kg}$ for thiamethoxam, with -0.0746 and -0.1091 of the upper $95 \%$ confidence intervals of dissipation rate constant, respectively. This work would be useful as guidance for adjusting the shipment date and contribute to stabilizing the income of farmers in Korea.

Keywords Dissipation rate constant - Mandipropamid · Preharvest residue limit . Thiamethoxam

\section{서 론}

농약은 병해충을 방제하고 농산물의 생산량 및 품질을 향상시 키기 위해 사용하는 현대농업의 필수불가결한 영농자재이다. 하 지만, 농약은 독성을 가지고 있으므로 농약성분이 잔존해 있는 농산물을 일반 소비자들이 섭취할 경우 건강유해성이 유발될 수 있다. 따라서, 농약 사용으로 얻을 수 있는 경제적 또는 사회적 이득을 극대화하고 환경 및 인체에 미치는 위해성은 최소화할 수 있도록 농약사용을 농약관리법에 따른 농약안전사용기준(Safe use guidelines)과 식품위생법의 농약잔류허용기준(Maximum Residue Limits, MRLs)으로 관리하고 있다.

농산물 출하 이후 안전성 검사에서 $\mathrm{MRLs}$ 을 초과할 경우 식 품위생법에 따라 폐기처분되어 생산자는 판매소득을 얻지 못해 큰 경제적 손실이 발생할 수 있다. 또한, 엽채류와 같은 신선농 산물은 유통 및 소비기간이 짧아 폐기조치되기 이전에 소비됨 
으로써 소비자의 건강 위해성을 초래할 수 있다. 이러한 문제 점을 해소하고 국민건강 보호 및 농가소득 향상을 위해 국내에 서는 생산단계 농약잔류허용기준(Pre-Harvest Residue Limits, PHRLs)을 추가로 설정 및 운용하고 있다. PHRLs은 잔류농약 의 시간경과별 소실특성을 활용하여 출하 예정일에서 출하 10 일전까지 일자별로 설정된 허용기준으로, 농약안전사용기준 및 $\mathrm{MRLs}$ 이 설정되어 있는 농약 및 농산물에 한해 설정하고 있다. 본 기준을 통해 출하시점의 농약잔류량이 MRLs을 상회할 경 우 출하를 지연시켜 잔류수준을 조절하거나 용도변경 조치를 취 하게 된다.

본 연구의 대상 작물인 상추(Lactuca sativa L.)는 대표적인 단기재배 작물로 우리나라 국민이 쌈채소로 빈번하게 소비하는 엽채류이다. 2018 년 기준 $3,773 \mathrm{ha}$ (엽채류 전체의 $7.4 \%$ )에서 재배되어 93,543 톤(엽채류 전체의 $3.0 \%$ )을 생산하였고 2,985 억 원(엽채류 전체의 13.4\%) 생산액을 보인 주요 엽채류이다[1,2]. 2017년부터 2020년 2월까지 국립농산물품질관리원에서 실시한 생산 및 출하단계 상추 2,672 건의 잔류농약 검사결과, 81 건이 MRLs을 초과하여 타 농산물에 비해 높은 $3.0 \%$ 의 부적합율을 보였다[3]. 따라서, 현재 상추에 acephate 등 20성분에 대한 PHRLs가 설정되어 있음에도 추가적인 PHRLs 설정이 요구되 는 상황이다.

Mandipropamid는 mandelamide계 보호용 살균제로 상추에 발 생하는 노균병 방제에 많이 사용되며, thiamethoxam은 우수한 침투이행성으로 약효가 오래 지속되어 상추에 큰 피해를 주고 있는 목화진딧물, 아메리카잎굴파리, 파밤나방 등을 방제하는데 효과적인 neonicotinoid계 살충제이다[4]. 앞선 연구에서 상추의 생육 및 수확시기에 따른 잔류농약 소실특성은 다수 보고되어 왔다[5,6]. 하지만, 최근 생산단계 조사결과 상추에 사용빈도가 높고 부적합율이 높아지고 있는 살균제 mandipropamid와 살충 제 thiamethoxam에 대해서는 아직 PHRLs가 설정되어 있지 않 아 이에 대한 연구가 필요하다.

따라서, 본 연구에서는 PHRLs 설정을 위한 과학적 기초자료를 확보하기 위해 시설재배 상추 중 mandipropamid와 thiamethoxam 의 초기 잔류특성, 시간경과에 따른 잔류량 소실 패턴 및 이에 미치는 요인을 규명하고자 하였다. 한편, 살충제 clothianidin은 과수, 엽채류의 진딧물, 총채벌레 등을 방제하기 위해 사용되는 농약으로 상추에는 사용 등록되어 있지 않지만 thiamethoxam의 주요 대사산물이기에 본 연구에서 잔류량을 추가 조사하였다[4].

\section{재료 및 방법}

\section{시약 및 초자}

작물 잔류포장시험용 농약제품은 상추에 사용 등록된 제품 중 유효함량이 가장 높은 제품으로 선정하였으며, 선정된 mandipropamid $22.59 \%$ 액상수화제(상표명: 레버스, (주)신젠타, Korea) 및 chlorantraniliprole+thiamethoxam $24.5(8+16.5) \%$ 액 상수화제(상표명: 볼리암후레쉬, (주)신젠타, Korea)은 농약판매 상으로부터 구매하였다. 잔류분 분석을 위한 표준품 mandipropamid (purity 98.5\%)은 Dr. Ehrenstorfer GmbH (Augsburg, Germany) 으로부터, thiamethoxam (purity 99.8\%) 및 clothianidin (purity 99\%)는 Sigma-Aldrich (St. Louis, MO, USA)로부터 구입하였

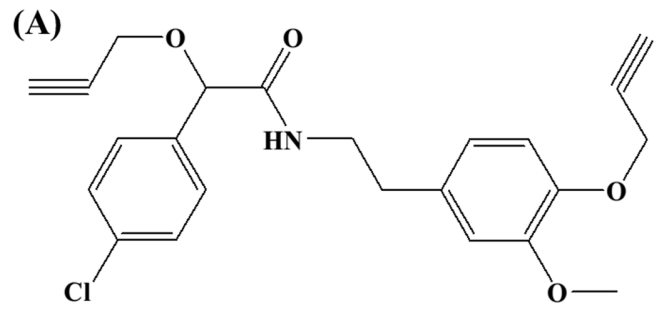<smiles>CN1COCN(Cc2cnc(Cl)s2)/C1=N/[N+](=O)[O-]</smiles><smiles>CN/C(=N\[N+](=O)[O-])NCc1cnc(Cl)s1</smiles>

Fig. 1 Chemical structures of mandipropamid (A), thiamethoxam (B) and clothianidin (C)

으며, 농약성분의 화학적 구조는 Fig. 1 와 같다. 작물체 중 농약 잔류량 분석을 위해 사용된 용매로 acetonitrile은 J.T. Baker ${ }^{\circledR}$ (Avantor, Radnor, PA, USA)의 High-Performance Liquid Chromatography (HPLC)급으로 구입하였고 dichloromethane, ethyl acetate, methanol, $n$-hexane은 Daejung Chemical \& Metals (Siheung, Korea)의 PR (pesticide residue)급을 사용하 였다. 고체시약인 sodium sulfate, anhydrous와 sodium chloride 는 GR (Guaranteed Reagent)급으로 Junsei Chemical Co. (Tokyo, Japan)에서 구입하였다. Ultrapure water $(18.2 \mathrm{M})$ 는 초 순수 조제장치 Direct-Q3 UV (Merck Millipore Co., Darmstadt, Germany)로 조제하여 사용하였다. 불순물 정제를 위한 open column chromatography용 정제 시약은 Merck (Darmstadt, Germany)의 Florisil 충진제 $(0.15-0.25 \mathrm{~mm})$ 를 사용하였다. 채취한 작물의 균 질화는 HALLDE (Stockholm, Sweden)의 VCB-61 균질기를 이용하여 진행하였고, 균질화된 시료로부터 농약성분을 추출하 기 위해 AM-7 homogenizer (Nihonseiki Kaisha Ltd., Tokyo, Japan)를 사용하였으며, 추출액 농축을 위한 회전감압농축기는 Buchi Labortechnik AG (Flawil, Switzerland)의 R-114를 사용 하였다.

\section{시험작물 및 포장시험}

작물 잔류시험용 포장지는 지리적 차이를 두기 위해 위도가 서 로 다르고 직선상의 거리가 최소 $20 \mathrm{~km}$ 이상 떨어진 지역으로 선정하였다. 선정된 포장지는 충북 진천군 초평면(포장 1$)$, 충 남 논산시 양촌면(포장 2), 전북 군산시 나포면(포장 3) 등 3지 역으로 포장시험은 해당지역에 위치한 시설(하우스)에서 2018년 1-4월에 수행되었다. 시험구는 포장지별 3반복구 및 1무처리구 로 구성하였고 반복구별 면적은 $7.0 \mathrm{~m} \times 1.4 \mathrm{~m}$ (포장 1), $9.6 \mathrm{~m}$ $\times 1.2 \mathrm{~m}$ (포장 2), $10.5 \mathrm{~m} \times 1.4 \mathrm{~m}$ (포장 3)이었으며 약제별 시험 구간의 완충지역을 $2 \mathrm{~m}$ 이상 두어 약제간 교차오염을 방지하였 다. 포장 1에서는 열풍((주)권농종묘) 품종을 2017년 11월에 정 식하였고 포장 2에서는 선풍 플러스((주)권농종묘) 품종을 2017 년 11월에, 포장 3에서는 열풍((주)권농종묘)을 2017년 12월에 정식하였으며 재식밀도는 $15 \mathrm{~cm} \times 15 \mathrm{~cm}$ 이었다. 약제살포는 약제 
Table 1 Safe use guidelines and maximum residue limit for mandipropamid and thiamethoxam on lettuce in Korea

\begin{tabular}{|c|c|c|c|c|c|c|}
\hline \multirow{2}{*}{ Pesticides } & \multirow{2}{*}{ Formulation } & \multirow{2}{*}{$\begin{array}{l}\text { a.i. }{ }^{1)} \\
(\%)\end{array}$} & \multicolumn{3}{|c|}{ Safe use guidelines } & \multirow{2}{*}{$\begin{array}{c}\mathrm{MRL}^{4)} \\
(\mathrm{mg} / \mathrm{kg})\end{array}$} \\
\hline & & & $\mathrm{PHI}^{2}$ (days) & $\mathrm{MAF}^{3)}$ (time) & Dilution & \\
\hline Mandipropamid & $\mathrm{WP}^{5)}$ & 22.59 & 5 & 2 & 3,000 & 30 \\
\hline Thiamethoxam + chloraniliprole & WP & $24.5(16.5+8)$ & 2 & 2 & 5,000 & 15 \\
\hline
\end{tabular}

${ }^{1)}$ Active ingredient

${ }^{2)}$ Pre-harvest interval

${ }^{3)}$ Maximum application frequency

${ }^{4)}$ Maximum residue limit

${ }^{5)}$ Wettable powder

별 안전사용기준[4]에 따라 2018년 1월 26일(포장 1), 2월 19 일(포장 2), 3월 13일(포장 3)에 1차 살포를 하였으며 최종 약 제살포 후 0 일차(약제 살포 후 2 시간 후)부터 $1,2,3,5,7$, 10 일차에 일자별로 시료를 채취하였다(Table 1). 약제살포는 배 부식 충전분무기(MSB20Li, Maruyama, Tokyo, Japan)를 이용 하였으며 살포 전 $2.1 \mathrm{kgf} / \mathrm{cm}^{2}$ 압력하에 일정량이 살포되도록 단 위시간당 살포속도를 3회 calibration한 다음 약 $930 \mathrm{~mL} / \mathrm{min}$ 약 량을 경엽 살포하였다. 시료채취는 정식 후 92일(포장 1), 91일 (포장 2), 103일(포장 3)차에 첫번째 채취가 진행되었으며 일자 별로 출하시기에 적합하고 생육상태가 일정한 개체를 최소 1 $\mathrm{kg}$ 이상 수확하였다. 채취된 시료는 polyethylene bag에 담은 후 ice box에 보관하여 24시간 이내에 실험실로 운반한 후 일 자별 중량변화를 측정하기 위해 상추 잎 50 개 묶음의 무게를 측정하였다. 채취한 시료는 dry ice와 함께 마쇄 및 분말화하여 균질화 시킨 후 polyethylene bottle에 담아 잔류분석때까지 -20 ${ }^{\circ} \mathrm{C}$ 이하의 냉동고에 보관하였다. 포장시험기간 동안 각 포장의 시설내 온도 및 습도는 TR-72U recorder (Thermo, Tokyo, Japan)를 이용하여 측정하였다.

\section{표준용액 조제 및 표준검량선 작성}

표준용액 조제를 위해 표준품 mandipropamid (순도 98.5\%) $10.152 \mathrm{mg}$, thiamethoxam (순도 99.8\%) $10.020 \mathrm{mg}$, clothianidin (순도 $99 \%$ ) $10.101 \mathrm{mg}$ 을 정밀히 달아 각각 acetonitrile 100 $\mathrm{mL}$ 에 녹여 $100 \mathrm{mg} / \mathrm{L}$ 농도의 stock solution을 조제하였다. 본 stock solution을 acetonitrile으로 단계적 희석하여 $0.02-5 \mathrm{mg} / \mathrm{L}$ 용액의 농약별 working solution을 조제하였다. 표준검량선은 각 농도별 working solution의 $20 \mu \mathrm{L}$ 를 HPLC-Ultraviolet-Visible Detector (UVD) 또는 Photo Diode Array detector (PDA)에 주입하여 나타난 chromatogram상의 peak 면적을 산출하고 농 도대비 peak 면적간의 회귀분석에 따라 작성하였으며, 검량선 직선성을 확인하기 위해 회귀분석에 따른 결정계수 $\left(\mathrm{R}^{2}\right)$ 를 산출 하였다. 조제된 stock solution은 실험기간 동안 $-4{ }^{\circ} \mathrm{C}$ 냉동고에 보관하였으며 보관 중 농약 모화합물의 분해는 발생하지 않았 다. 한편, working solution은 분석 시 마다 stock solution을 이 용해 조제하여 농약 잔류량 정량분석에 활용하였다.

\section{상추 중 잔류농약 HPLC 분석}

상추 중 잔류농약 분석을 위해 고성능액체크로마토그래피(HPLC) 인 Shimazu Prominence 20 series HPLC (Shimadzu Corp., Kyoto, Japan)를 사용하였다. Mandipropamid 분석을 위해 칼럼 Phenomenex Luna C18 $(250 \times 4.6 \mathrm{~mm}, 5 \mu \mathrm{m}$, Torrance, CA, USA $)$
에 acetonitrile과 water을 55:45 비율로 조제한 이동상을 유속 $1.0 \mathrm{~mL} / \mathrm{min}$ 으로 흘려준 후 PDA인 SPD-M20A을 이용해 mandipropamid를 $226 \mathrm{~nm}$ 에서 검출하였다. Thiamethoxam 및 clothianidin 분석은 칼럼 Agilent Eclipe XDB-C8 $(250 \times 4.6 \mathrm{~mm}, 5 \mu \mathrm{m}$, Santa Clara, CA, USA)에 acetonitrile과 water로 구성된 이동 상을 유속 $0.8 \mathrm{~mL} / \mathrm{min}$ 으로 흘려준 gradient 조건하에서 이루어 졌으며, $\mathrm{UVD}$ 인 $\mathrm{SPD}-20 \mathrm{AV}$ 를 활용해 $258 \mathrm{~nm}$ 에서 잔류분을 검 출하였다. Gradient 조건을 위해 $10 \%$ acetonitrile을 3 분간 흘려 주고 5 분동안 acetonitrile 비율을 $35 \%$ 로 높인 후 5 분간 유지하 였고 2 분내에 acetonitrile 비율을 $10 \%$ 로 낮추었다. 칼럼의 온도 는 $40{ }^{\circ} \mathrm{C}$ 이었으며, 기기주입량은 $20 \mu \mathrm{L}$ 이었다.

\section{상추 중 잔류농약 추출 및 정제}

상추 중 mandipropamid, thiamethoxam 및 clothianidin의 잔류 농약 분석은 식품공전[7] 분석법을 변형하여 확립된 분석법으로 이루어졌다. 상추 중 mandipropamid 잔류분석을 위해 균질화된 상추 시료 $25 \mathrm{~g}$ 을 추출용기에 담고 methanol $100 \mathrm{~mL}$ 를 첨가한 다음 $12,000 \mathrm{rpm}$ 으로 2 분간 고속마쇄추출하고 감압여과한 다음 잔여물을 methanol $40 \mathrm{~mL}$ 로 세척하여 앞선 여과액과 합하였다. 추출물을 감압 농축하지 않고, $1,000 \mathrm{~mL}$ separating funnel에 옮 긴 후 water $300 \mathrm{~mL}$ 와 sat. $\mathrm{NaCl}$ solution $50 \mathrm{~mL}$ 와 합한 다음 dichloromethane $50 \mathrm{~mL}$ 로 2 회 액액분배하였다. 분배 후 유기용 매층을 sodium sulfate, anhydrous에 통과시켜 수분을 제거하고 $40{ }^{\circ} \mathrm{C}$ water bath에서 감압농축을 한 후에 $n$-hexane $10 \mathrm{~mL}$ 으로 재용해하였다. Glass column (40 cm, $18 \mathrm{~mm}$ I.D.)에 $130^{\circ} \mathrm{C}$ 에 서 5시간 이상 활성화된 Florisil $10 \mathrm{~g}$ 을 넣고 그 위에 sodium sulfate, anhydrous 약 $2 \mathrm{~g}$ 을 충전하였다. 충진제를 $n$-hexane 50 $\mathrm{mL}$ 로 세척한 다음 재용해액 $10 \mathrm{~mL}$ 를 가한 후 약 $3 \mathrm{~mL} / \mathrm{min}$ 의 유속으로 흘려보냈다. Ethyl acetate/n-hexane (20/80, v/v) 100 $\mathrm{mL}$ 로 씻어내고 ethyl acetate $/ n$-hexane $(50 / 50, \mathrm{v} / \mathrm{v}) 100 \mathrm{~mL}$ 를 용출 받아 $40{ }^{\circ} \mathrm{C}$ 상에서 감압농축한 후, acetonitrile $25 \mathrm{~mL}$ 로 재 용해하고 $0.2 \mu \mathrm{m}$ filter로 여과하여 시험용액을 조제하였다.

상추 중 thiamethoxam 및 clothianidin 잔류량 정량분석을 위 해 균질화된 시료 $20 \mathrm{~g}$ 을 추출용기에 담고 $80 \%$ acetonitrile $100 \mathrm{~mL}$ 를 첨가한 다음 $12,000 \mathrm{rpm}$ 으로 3 분간 고속마쇄추출하고 감압여과한 다음 잔여물을 acetonitrile $50 \mathrm{~mL}$ 으로 추가 세척하 여 앞선 여과액과 합하였다. 추출물을 $1,000 \mathrm{~mL}$ separating funnel에 옮긴 후 water $450 \mathrm{~mL}$ 및 sat. $\mathrm{NaCl}$ solution $50 \mathrm{~mL}$ 와 합한 다음 dichloromethane 100 및 $50 \mathrm{~mL}$ 로 2회 액액분배하였 다. 분배액을 sodium sulfate, anhydrous에 통과시켜 수분을 제 거한 후 $40{ }^{\circ} \mathrm{C}$ 에서 감압농축을 하고 dichloromethane $10 \mathrm{~mL}$ 으 
로 재용해하였다. Glass column $(40 \mathrm{~cm}, 11 \mathrm{~mm}$ I.D.)에 130 ${ }^{\circ} \mathrm{C}$ 에서 5 시간 이상 활성화된 Florisil $5 \mathrm{~g}$ 을 넣고 그 위에 sodium sulfate, anhydrous 약 $2 \mathrm{~g}$ 을 충전한 다음 dichloromethane 25 $\mathrm{mL}$ 로 세척하였다. Column에 재용해액 $10 \mathrm{~mL}$ 를 가해 흘려주고 acetone/dichloromethane $(5 / 95, \mathrm{v} / \mathrm{v}) 50 \mathrm{~mL}$ 를 넣어 세척한 다음 acetone/dichloromethane $(45 / 55, \mathrm{v} / \mathrm{v}) 100 \mathrm{~mL}$ 으로 농약성분을 용출시켰다. 용출액을 $40{ }^{\circ} \mathrm{C}$ 상에서 감압농축 한 후, $20 \%$ acetonitrile $20 \mathrm{~mL}$ 로 재용해하고 $0.2 \mu \mathrm{m}$ filter로 여과하여 시험 용액을 조제하였다.

\section{분석정량한계, 회수율 및 저장안정성 시험}

농약성분별 chromatogram상에서 signal to noise ratio $(\mathrm{s} / \mathrm{n})$ 가 3 인 농도를 기기상의 검출한계로, $\mathrm{s} / \mathrm{n} 10$ 이상인 농도를 기기상 의 정량한계로 결정하였다. 분석 방법정량한계(Method Limit of Quantitation, MLOQ)는 결정된 기기상의 정량한계, 기기주입량, 전처리과정의 시료채취량, 최종 시험용액량, 분석과정 중 희석 또는 농축배수를 고려하여 결정하였다[8]. 상추 중 잔류농약 정 량분석법의 정확성 및 정밀성을 검증하기 위해 회수율 시험을 진행하였다. 상추 무처리구 시료에 각 농약 표준용액을 첨가하 여 시료 중 농도가 $10 \mathrm{MLOQ}$ 및 MRL (mandipropamid $30 \mathrm{mg} / \mathrm{kg}$, thiamethoxam 및 clothianidin $15 \mathrm{mg} / \mathrm{kg}$ ) 수준이 되도록 처리하 였다. 포장시험에서 채취한 시료의 분석이 완전히 종료될 때까 지 냉동보관하는 동안 잔류농약의 안전성을 검증하기 위해 저 장안전성 시험을 실시하였다. 처리수준은 $\mathrm{MRL}$ 수준이었고 농 약성분별 보관기간은 mandipropamid 120일, thiamethoxam 및 clothianidin 232일이었다. 회수율 및 저장안정성 시험은 처리수 준별 3 반복 실험하였으며, 회수율의 평균값과 변이계수 (Coefficient of Variation, C.V.; standard deviation/average $\times 100$, $\%)$ 를 산출하였다.

\section{상추 중 잔류농약의 감소양상}

상추에 농약약제 살포 후 잔류량의 감소 양상을 확인하기 위해 잔류량 감소상수를 산출하였다. 농약 잔류량과 경과시간 요인간 의 상관성을 규명하기 위해 상관분석(correlation analysis) 하였 으며, 잔류량 감소는 단순 1 차 감쇄반응으로 관찰된다는 점에 근거하여 1 차 회귀방정식 $\mathrm{dR} / \mathrm{dt}=\lambda \mathrm{R}, \mathrm{R}=\mathrm{R}_{0} \times \mathrm{e}^{-\lambda \mathrm{t}}\left(\ln \mathrm{R}=\ln \mathrm{R}_{0}\right.$ $-\lambda \mathrm{t})\left(\mathrm{R}\right.$ 잔류량, $\mathrm{R}_{0}$ 초기 잔류량, $\lambda$ 감소상수, $\mathrm{t}$ 시간)에 따른 회귀분석(regression analysis)을 진행하였다. 회귀방정식의 유의 성을 검증하기 위해 결정계수 $\left(\mathrm{R}^{2}\right.$, coefficient of determination) 와 분산분석을 거쳐 $\mathrm{F}$-검정을 수행하였다. 회귀분석에 따른 초 기 잔류량 $\left(\mathrm{R}_{0}\right)$ 및 감소상수 $(\lambda)$ 의 평균 및 $95 \%$ 신뢰구간(CI, $95 \%$ confidence interval)을 산출하기 위해 감소상수인 회귀계수에 대 해 t-검정을 수행하였다. 생물학적 반감기는 앞서 산출된 감소 상수 $(\lambda)$ 를 이용하여 산출하였다 $\left(\mathrm{T}_{1 / 2}=\ln 2 \div \lambda\right)$. 앞선 모든 통계 분석은 통계프로그램인 SPSS(ver 18.0, SPSS Inc., Armonk, $\mathrm{NY}, \mathrm{USA})$ 를 이용하여 수행되었다.

\section{출하전 일자별 생산단계 잔류허용기준 산출}

앞선 일자별 잔류량의 회귀분석을 통해 산출된 감소상수 $(\lambda)$ 의 $95 \%$ 신뢰구간 상한치(UCL, 95\% upper confidence limit)를 결 정하고 상추 중 mandipropamid 및 thiamethoxam의 잔류허용기 준(MRL)을 토대로 출하전 일자별 잔류량을 추정하여 생산단계 잔류허용기준(Pre-Harvest Residue Limit, PHRL)으로 결정하였다.

\section{출하전 일자의 생산단계 잔류허용기준 $\left(\mathrm{PHRL}_{\mathrm{t}}\right)=\mathrm{MRL} \times \lambda^{\mathrm{UCL}(\lambda) \mathrm{t}}$}

OECD MRL calculator를 이용한 농약 잔류허용기준 재평가 상추에 등록되어 있는 mandipropamid 및 thiamethoxam 안전사 용기준 중 살포 후 수확일 $(\mathrm{PHI})$ 은 각각 5 일 및 2일이며, $\mathrm{OECD}$ MRL calculator를 이용하여 mandipropamid 및 thiamethoxam의 PHI 잔류량에 따른 농약 잔류허용기준을 추정하였다 $[9,10]$.

\section{결과 및 고찰}

\section{포장시험 재배환경 및 상추 생육}

포장별 시설내 평균기온은 포장 $110.5 \pm 1.9^{\circ} \mathrm{C}$, 포장 $211.5 \pm 3.6$ ${ }^{\circ} \mathrm{C}$, 포장 $320.8 \pm 2.9^{\circ} \mathrm{C}$ 로 포장 1 이 가장 낮고 포장 2 는 포장 1 보다 다소 기온이 높은 수준이었으나 포장 3 은 포장 2에 비해 평균 약 $9{ }^{\circ} \mathrm{C}$ 높았다(Fig. 2). 포장 1 의 시험시기는 1 월말-2월중 순이었고 포장 2는 2월중순-3월초이었던 반면, 포장 3은 3월중 순-4월초이었기에 상대적으로 시설내 기온이 높았으며, 포장소
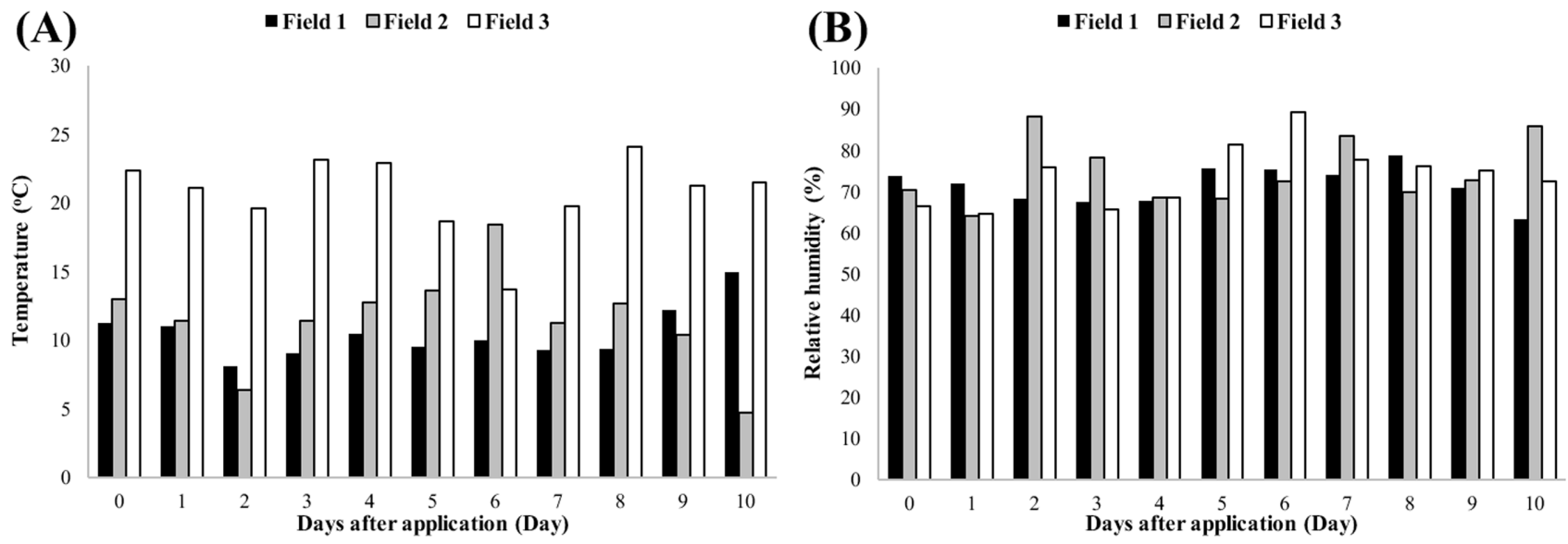

Fig. 2 Climatic condition of average temperature (A) and relative humidity (B) in lettuce fields during the experimental period 

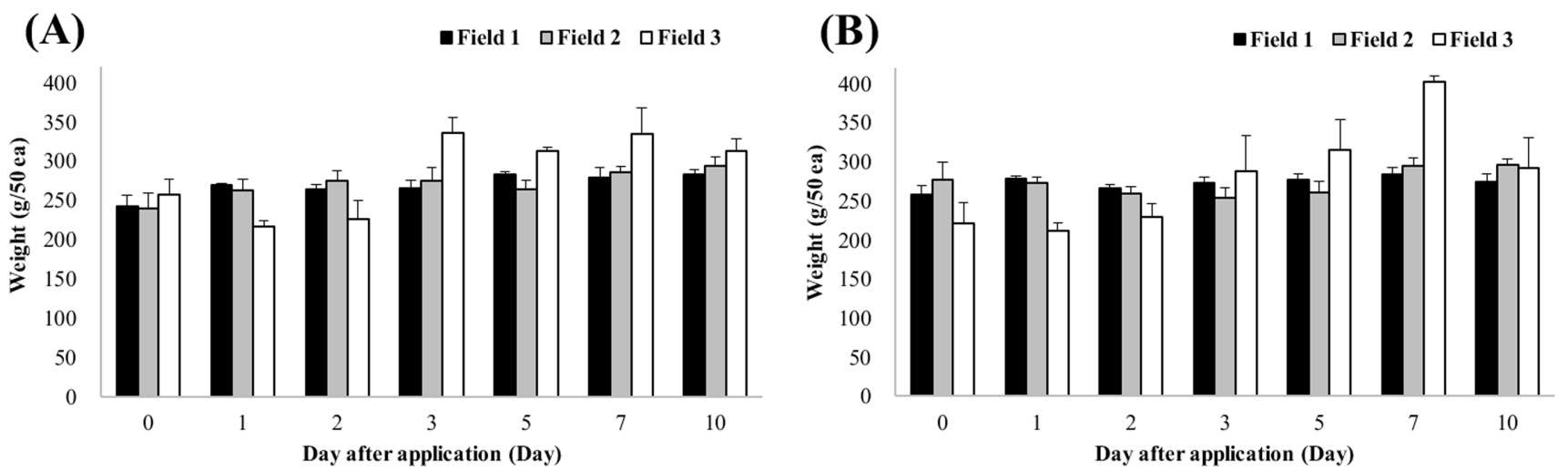

Fig. 3 The weight distribution of lettuce collected during the experimental period after applying with mandipropamid (A) and thiamethoxam (B)

재지도 위도상으로 가장 낮은 곳이 포장 3 , 군산지역이었다. 농 약제품 등록을 위한 포장시험은 엽채류의 경우 4월이내에 수행 해야 하며, 본 연구의 포장시험 시기에는 문제가 없었다. 포장 별 시설내 습도는 포장별 평균 71.6-74.0\%로 포장별 유의적 차 이가 없었으며(Fig. 2), 특정일자에 습도가 높은 경우는 해당일 의 강우에 의한 영향이었다.

채취 일자별 상추(50개 묶음)의 무게를 살펴보면, mandipropamid의 경우 포장별 각각 $273.1 \pm 10.8 \mathrm{~g}$ (포장 1), $273.8 \pm$ $19.2 \mathrm{~g}$ (포장 2), $280.2 \pm 68.4 \mathrm{~g}$ (포장 3)이었고 thiamethoxam 포 장의 상추 무게는 $270.0 \pm 15.2 \mathrm{~g}$ (포장 1), 271.1 $\pm 20.3 \mathrm{~g}$ (포장 2), $285 \pm 50.9 \mathrm{~g}$ (포장 3)으로 채취일자가 경과하면서 다소 상추 의 무게가 증가하였으나 포장별 유의적 차이는 보이지 않았다 (Fig. 3). 0일차 대비 10일차의 상추 증체율은 6.5-32.1\%이었으 며 포장 3 의 증체율이 다른 포장의 상추보다 높은 것은 앞서 언급한 포장시험 수행시기 차이에 의한 것으로 사료된다.

\section{분석정량한계, 회수율 및 저장안정성}

본 연구의 대상 농약들의 화학구조는 Fig. 1과 같다. Mandipropamid은 $\log \mathrm{P}_{\mathrm{ow}}$ (물/옥탄올 계수) 3.2인 비극성 중성화합물 이며 휘발성이 낮고 분자 내에 3 중결합을 포함하고 있어 기체 크로마토그래피(Gas Chromatography, GC)로 분석하기 어려우 나 분자구조 상 자외 흡광 특성이 우수하여 자외흡광분석기 (Ultra Violet Detector, UVD)가 장착된 액체크로마토그래피 (HPLC)로 정량하는 분석법을 고려하였다. Thiamethoxam 및 clothianidin은 neonicotinoid계 살충제로서 $\log \mathrm{P}_{\mathrm{ow}}$ 값이 각각 -0.13 , 0.70 으로 극성이 크고 증기압이 낮은 비휘발성 화합물이기에 HPLC-UVD를 이용한 분석법으로 검토하였다[11].

기기상의 검출한계는 기기분석 시 크로마토그램상에서 존재 유무가 확인 가능한 분석물질의 최소농도를 의미하며, 기기상의 정량한계는 기기분석을 통해 정량할 수 있는 분석물질의 최소 농도를 의미한다. 다양한 농도의 working solution을 조제하여 기기분석한 결과, mandipropamid의 기기상의 정량한계는 0.04 $\mu \mathrm{g} / \mathrm{mL}$ 이었고 thiamethoxam 및 clothianidin은 각각 $0.02 \mu \mathrm{g} / \mathrm{mL}$ 이었다. 전처리 및 기기분석을 통해 정량할 수 있는 시료상의 최소농도를 의미하는 분석 방법정량한계(MLOQ)는 mandipropamid $0.04 \mathrm{mg} / \mathrm{kg}$, thiamethoxam 및 clothianidin $0.02 \mathrm{mg} / \mathrm{kg}$ 이었다. 정량분석을 위한 표준검량선을 작성한 결과, 결정계수 $\left(\mathrm{R}^{2}\right)$ 가 모
Table 2 Recovery rate and limit of quantification for mandipropamid, thiamethoxam and clothianidin in lettuce

\begin{tabular}{cccc}
\hline \hline Pesticides & $\begin{array}{c}\text { Fortification } \\
\text { level }(\mathrm{mg} / \mathrm{kg})\end{array}$ & $\begin{array}{c}\text { Recovery } \\
\text { rate }^{1)}(\%)\end{array}$ & $\begin{array}{c}\mathrm{MLOQ}^{2)} \\
(\mathrm{mg} / \mathrm{kg})\end{array}$ \\
\hline Mandipropamid & 0.4 & $90.4 \pm 4.8$ & 0.04 \\
& 30 & $96.8 \pm 0.9$ & \\
\hline Thiamethoxam & 0.2 & $112.5 \pm 0.6$ & 0.02 \\
& 15 & $99.8 \pm 0.2$ & \\
\hline Clothianidin & 0.2 & $100.6 \pm 0.2$ & 0.02 \\
& 15 & $99.8 \pm 0.04$ & \\
\hline
\end{tabular}

${ }^{11}$ Mean \pm C.V. (coefficient of variation), $\mathrm{n}=3$

${ }^{2)}$ Method limit of quantification

Table 3 Storage stability of mandipropamid, thiamethoxam and clothianidin in lettuce

\begin{tabular}{cccc}
\hline \hline Pesticides & $\begin{array}{c}\text { Fortification } \\
\text { level (mg/kg) }\end{array}$ & $\begin{array}{c}\text { Storage period } \\
\text { (days) }\end{array}$ & $\begin{array}{c}\text { Recovery rate } \\
(\%)\end{array}$ \\
\hline Mandipropamid & 30 & 120 & $101.2 \pm 1.0$ \\
Thiamethoxam & 15 & 232 & $97.5 \pm 1.4$ \\
Clothianidin & 15 & 232 & $99.8 \pm 0.2$ \\
\hline
\end{tabular}

${ }^{1)}$ Mean \pm C.V. (coefficient of variation), $n=3$

두 0.999 이상으로 검량선 작성 농도범위내의 우수한 직선성을 확인할 수 있었다. 크로마토그램 상 mandiproamid, thiamethoxam 및 clothianidin의 머무름 시간은 각각 $11.5,9.2,10.2 \mathrm{~min}$ 이었 고 무처리 시료 분석결과, 크로마토그램 상에서 시험농약 성분 과 겹치는 분석 방해물질은 없었다. 잔류분석법에 따른 회수율 확인결과, 모든 처리수준에서 평균 회수율 $90-112 \%$, C.V.값 $5 \%$ 미만을 보임으로써(Table 2). 회수율 검증기준인 70-110\%, C.V. $20 \%$ 미만을 만족하여 분석방법의 정확성 및 정밀성을 확보하 였다[12]. 저장안정성 시험에서 회수율 97-101\%, C.V.값 $2 \%$ 미 만의 결과를 보여 저장기간 동안 분석대상물질의 분해 및 소실 이 발생하지 않았음을 확증할 수 있었다(Table 3).

상추 Mandipropamid 및 Thiamethoxam의 잔류량

상추 출하가능 기간 중 mandipropamid 및 thiamethoxam의 잔 

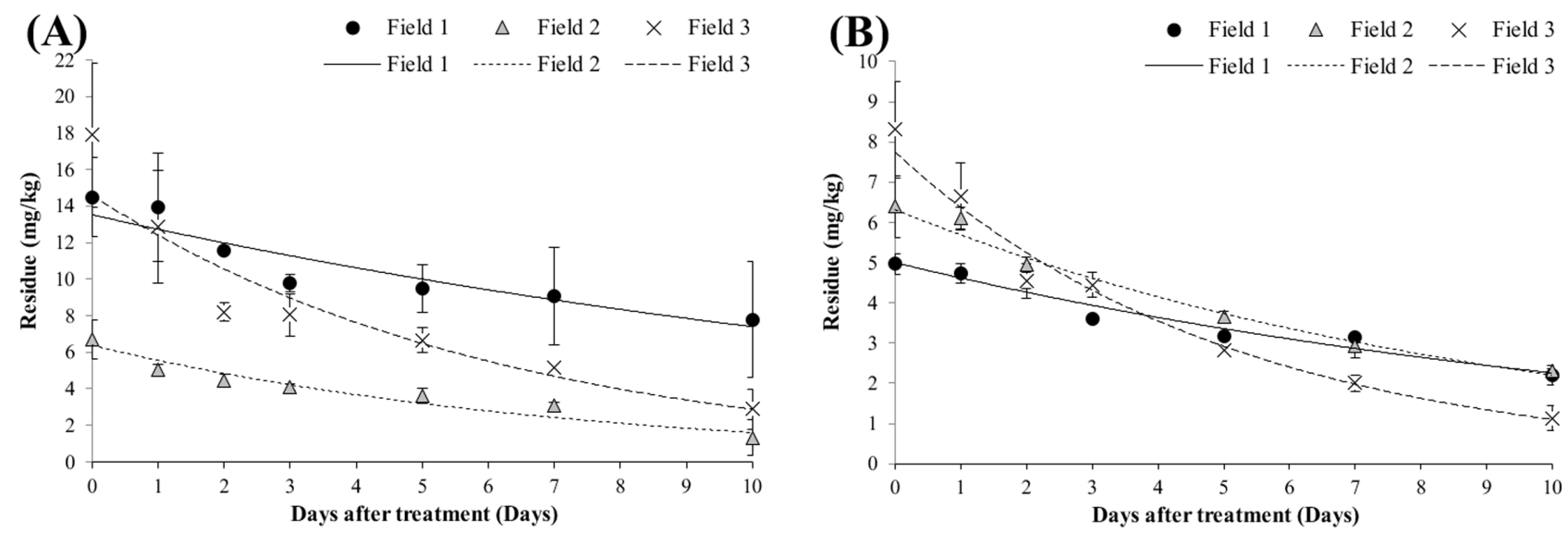

Fig. 4 Residue changes of mandipropamid (A) and thiamethoxam (B) in lettuce during the experimental period

류수준과 변화를 확인하였다. Mandipropamid 약제살포 후 상추 의 초기 평균 잔류량은 14.49 (포장 1), 6.68 (포장 2), 17.87 (포장 3) $\mathrm{mg} / \mathrm{kg}$ 이었으나, thiamethoxam의 경우 4.96 (포장 1), 6.40 (포장 2), 8.31 (포장 3) $\mathrm{mg} / \mathrm{kg}$ 으로 mandipropamid의 초기 잔류량이 1.0-2.9배 높았다(Fig. 4). 초기 잔류량은 작물 생육상 태, 살포압력, 살포거리, 살포액적 크기, 살포자의 살포습관, 포 장지 온습도 등 다양한 요인에 의해 크게 영향을 받기 때문에 특정요인에 의한 것이라 단정하기는 어렵다[13-15]. 그러나, 두 약제 모두 7 일간격 2회 살포로 살포 횟수는 동일하나 농약제품 의 유효성분 함량은 mandipropamid가 약 1.37 배 높고 희석배 수는 1.67 배 낮아 1 회 살포 시 단위면적당 약 2.29 배 많이 살 포되었기 때문에 mandipropamid의 초기 잔류량이 높은 것으로 추정된다(Table 1). 앞서 보고된 엇갈이배추의 mandipropamid 잔류연구에서는 본 연구보다 단위면적당 약 1.4 배 많은 약량을 3 회 살포하여 본 연구결과와 유사한 $12.7-15.3 \mathrm{mg} / \mathrm{kg}$ 의 초기 잔 류량을 보였고[16], thiamethoxam의 경우 본 연구와 동일한 2 회 살포에 단위면적당 살포액이 약 1.5 배 높았으나 초기잔류량 이 $0.649 \mathrm{mg} / \mathrm{kg}$ 으로 본 연구에서의 초기 잔류량보다 7.6 배 이 상 낮았다[17]. 요컨데, 본 연구결과와의 비교분석을 통해 농약 살포액적이 엇갈이배추보다 상추 표면에 단위중량당 부착량이 더 많고 살포 횟수가 늘어날 수록 잔류량이 크게 증가함을 알 수 있었다.

약제살포 후 시간이 경과할수록 잔류량은 감소하였으며, 10 일 경과 후 mandipropamid 및 thiamethoxam의 평균 잔류량은 각각 초기 평균 잔류량의 $16-54 \%$ 및 $14-44 \%$ 수준이었다(Fig. 4). 포장별로 살펴보면, 초기 잔류량 대비 10 일차 잔류량이 포 장 1 에서는 $44-54 \%$, 포장 2 는 $20-36 \%$, 포장 3 은 $14-16 \%$ 이었 다. 이를 통해, 포장 재배기온이 높을수록 잔류량 감소폭이 증대됨 을 확인할 수 있었다. 상추 중 mandipropamid 및 thiamethoxam의 살포 후 수확일 $(\mathrm{PHI})$ 잔류량은 각각 3.17-10.44 및 4.14-5.14 $\mathrm{mg} / \mathrm{kg}$ 으로 잔류허용기준(MRL)인 30 및 $15 \mathrm{mg} / \mathrm{kg}$ 미만이었다 (Table 1, Fig. 4). 한편, thiamethoxam의 대사산물인 clothianidin 은 별도의 살충제로 국내에 사용되고 있지만 상추에는 사용등 록되어 있지 않다. 따라서, thiamethoxam 사용에 따른 상추 중 clothianidin 잔류량을 확인할 필요가 있었다. 포장 1 및 2에서 는 모든 시료에서 clothianidin이 검출되지 않았고, 포장 3에서
는 thiamethoxam 살포 후 수확일인 2 일차에 $<0.02,0.34$ 및 $0.37 \mathrm{mg} / \mathrm{kg}$ 로 검출되어 $0.24 \pm 0.20 \mathrm{mg} / \mathrm{kg}$ 의 잔류량을 보였다. 그 러나, clothianidin의 엽채류 기준 $3.0 \mathrm{mg} / \mathrm{kg}$ 미만이었기에 안전 성에는 문제가 없었다.

\section{상추 재배 중 잔류농약의 감소상수 및 생물학적 반감기}

상추 수확일자 경과에 따른 잔류소실 특성을 확인하기 위해 일 자별 잔류량을 토대로 상관분석 및 단순회귀분석을 수행하였으 며 잔류농약의 감소상수 및 생물학적 반감기를 산출하였다(Table 4). 상관분석 결과, 상관계수(r, coefficient of correlation)는 모두 0.9 이상으로 경과시간과 잔류량간 높은 상관성을 보였다. 회귀 분석에 따른 결정계수 $\left(\mathrm{R}^{2}\right)$ 는 모두 0.8 이상이었고 mandipropamid 의 포장 1 을 제외하면 0.9 이상의 높은 결정력을 보였으며, F-검 정결과 모든 농약성분 및 포장별 회귀식의 적합성이 확인되었다.

포장별 평균 감소상수는 mandipropamid -0.1624- -0.0603 , thiamethoxam $-0.1952--0.0796$ 으로, 이에 따른 생물학적 반감 기는 mandipropamid 4.3-11.5일, thiamethoxam 3.6-8.7일이었다 (Table 4). 포장구분없이 일자별 잔류량 회귀식을 산출할 경우, mandipropamid과 thiamethoxam의 감소상수 평균값은 각각 -0.1060 및 -0.1236 이고 생물학적 반감기는 각각 6.5 일 및 5.6 일이었다. 상추는 약산성 $(\mathrm{pH}$ 5.89-6.09)이며 두 농약성분은 해당 $\mathrm{pH}$ 범위 의 가수분해로부터 안정하므로 $[11,18]$ 농약성분의 분해특이성은 없었으며, 두 농약성분의 감소추이 간에는 유의적 차이 $(p<0.05)$ 가 없었다. 상추 중 mandipropamid 및 thiamethoxam의 잔류소 실특성에 대해 앞서 보고된 문헌이 부재하여 타 작물을 대상으 로 한 소실특성을 비교분석해보면, 엇갈이배추 중 mandipropamid 의 반감기는 3.9-4.0일로 본 연구 중 포장 3 의 반감기와 유사한 수준이었고 포장구분없이 산출된 반감기 6.5일보다는 짧았다[16]. Thiamethoxam의 경우, 엇갈이배추의 반감기가 2.3일[17]이었고 근대의 반감기는 본 연구의 상추 반감기와 유사한 4.2-6.3일의 반감기를 보였다[19]. 딸기의 thiamethoxam 반감기는 9일[20]이 었다. 한편, 엇갈이배추 잔류포장시험은 mandipropamid의 경우 5월말, thiamethoxam의 경우 7월에 이루어져 재배기간 중 기온 이 상대적으로 높고 생장이 급격하게 증가하였기 때문에 소실 특성에 대한 본 연구결과와의 단순비교에는 제한점이 있었다 $[16,17]$. 이에 반해, 근대 중 thiamethoxam 잔류포장시험의 기 
Table 4 Linear fit of the data for the dissipation rates of mandipropamid and thiamethoxam in lettuce

\begin{tabular}{cccccccc}
\hline \hline Pesticides & Fields & $\mathrm{r}$ & $\mathrm{R}^{2}$ & $\ln \mathrm{R}_{0} \pm \mathrm{CI}(95 \%)$ & $\lambda \pm \mathrm{CI}(95 \%)$ & $\mathrm{F}$ value \\
\hline \multirow{3}{*}{ Mandipropamid } & $\# 1$ & -0.9328 & 0.8702 & $2.6040 \pm 0.1388$ & $-0.0603 \pm 0.0268$ & 33.5 \\
& $\# 2$ & -0.9599 & 0.9214 & $1.8527 \pm 0.2403$ & $-0.1380 \pm 0.0463$ & 58.6 \\
& $\# 3$ & -0.9698 & 0.9404 & $2.6806 \pm 0.2436$ & $-0.1624 \pm 0.0470$ & 78.9 \\
\cline { 2 - 7 } & Total & -0.9683 & 0.9376 & $2.4275 \pm 0.1629$ & $-0.1060 \pm 0.0314$ & 75.1 \\
\hline \multirow{3}{*}{ Thiamethoxam } & $\# 1$ & -0.9752 & 0.9511 & $1.6091 \pm 0.1076$ & $-0.0796 \pm 0.0208$ & 97.2 \\
& $\# 2$ & -0.9935 & 0.9870 & $1.8433 \pm 0.0720$ & $-0.1053 \pm 0.0139$ & 378.7 \\
& $\# 3$ & -0.9948 & 0.9897 & $2.0475 \pm 0.1186$ & $-0.1952 \pm 0.0228$ & 481.3 \\
\cline { 2 - 7 } & Total & -0.9947 & 0.9895 & $1.8370 \pm 0.0758$ & $-0.1236 \pm 0.0145$ & 471.4 \\
\hline
\end{tabular}

Table 5 Pre-harvest residue limits (PHRLs) estimated from 95\% upper confidence limit of dissipation rate constant $(\lambda)$ for mandipropamid and thiamethoxam

\begin{tabular}{cccccc}
\hline \hline \multirow{2}{*}{ Pesticides } & \multicolumn{3}{c}{ UCL, 95\% upper confidence limit } & \multicolumn{2}{c}{ Estimates of PHRLs $(\mathrm{mg} / \mathrm{kg})$} \\
\cline { 2 - 6 } & $\mathrm{R}_{0}(\mathrm{mg} / \mathrm{kg})$ & $\lambda$ & $\mathrm{T}_{1 / 2}($ days $)$ & 10 days before & 5 days before \\
\hline Mandipropamid & 13.3 & -0.0746 & 9.3 & 63.24 & 43.56 \\
Thiamethoxam & 6.8 & -0.1091 & 6.4 & 44.66 & 25.88 \\
\hline
\end{tabular}

온은 $19.5-19.6{ }^{\circ} \mathrm{C}$, 습도는 $68.4-73 \%$ 로 본 연구 중 포장 3 의 재배조건과 유사하였다.

문헌과의 비교분석결과, 잔류량 감소양상은 작물종류, 품종, 생육상태, 재배시기, 살포방법 등 다양한 요인들에 영향을 받지 만 그 중 재배기온과 그에 따른 증체율이 잔류농약 반감기를 결정하는 주요 요인이었음을 확인할 수 있었다. 또한, 생산단계 잔류허용기준 설정과 관련되어 앞서 보고된 많은 문헌들은 4월 이후에 포장시험을 수행하거나 수확일자별 출하가능한 농산물 을 수확하지 않고 산출된 잔류양상들을 보고하였다. 따라서, 앞 서 보고된 생산단계 중 잔류농약 감소양상 연구에 대한 보완연 구가 필요하며, 잔류소실특성을 보수적으로 평가하기 위해 포장 시험간 변이를 반영하여야 할 것으로 사료된다.

\section{상추 중 소실특성을 이용한 PHRLs 추정}

상추 중 mandipropamid와 thiamethoxam의 잔류 및 소실특성이 반영된 회귀분석 결과를 토대로 생산단계 잔류허용기준(PHRLs) 를 결정하였다. 잔류량 소실특성을 보수적으로 평가하고 포장시 험간 변이를 반영하기 위해 포장별 구분없이 모든 일자별 잔류 량을 토대로 감소상수의 $95 \%$ 신뢰구간 상한치(UCL, 95\% upper confidence limit)를 산출하여 PHRLs 결정에 이용하였다 (Table 5).

Mandipropamid 또는 thiamethoxam을 상추에 살포하였을 때 살포당일 초기 잔류량의 $95 \%$ 신뢰구간 상한치는 각각 13.3 또 는 $6.8 \mathrm{mg} / \mathrm{kg}$ 으로, 현재 잔류허용기준의 약 $1 / 2$ 수준이었다. Mandipropamid 또는 thiamethoxam 감소상수의 $95 \%$ 신뢰구간 상한치는 각각 -0.0746 또는 -0.1091 이었고 이에 대한 반감기 는 9.3 일 또는 6.4 일이었다. 상추 중 mandipropamid 또는 thiamethoxam의 잔류허용기준이 30 또는 $15 \mathrm{mg} / \mathrm{kg}$ 이므로 출하 10 일 및 5 일 전의 PHRLs은 mandipropamid의 경우 각각 63.24 및 $43.56 \mathrm{mg} / \mathrm{kg}$ 로 산출되었고, thiamethoxam은 각각 44.66 및 $25.88 \mathrm{mg} / \mathrm{kg}$ 으로 산출되었다. 본 연구에서는 약제별 포장조건별 잔류 및 소실특성을 규명하였으며, 이를 토대로 상추를 수확하
고자 하는 특정시점의 mandipropamid 및 thiamethoxam 잔류량 과 불확실도 범위를 추정하였다. 본 연구결과는 농가에서 재배 시기 또는 출하시점을 조절하는데 활용될 수 있으며, 이를 통 해 농가의 소득 안정화 및 소비자의 건강안전성에 기여할 것으 로 사료된다.

한편, OECD MRL calculator를 통해 추정된 mandipropamid 및 thiamethoxam의 MRLs은 현재 설정되어 있는 MRL 20 및 $15 \mathrm{mg} / \mathrm{kg}$ 와 동일하였다. 따라서, 본 연구를 통해 현재 설정되어 있는 상추 중 MRLs의 적합성을 재확인하였다.

\section{초 록}

상추 중 살균제 mandipropamid 및 살충제 thiamethoxam의 생 산단계 잔류허용기준(PHRLs)를 추정하기 위해 3곳의 상추 시 설재배지에서 두 약제의 경시적 잔류량 감소특성을 조사하였다. 상추 중 농약 잔류량은 HPLC-PDA 또는 UVD를 이용하여 분 석하였으며 우수한 회수율 및 변이값을 보여 분석의 유효성을 확보하였다. 농약안전사용기준에 따라 약제살포 권고량을 살포 한 후 살포 후 수확일 $(\mathrm{PHI})$ 을 포함한 10 일 동안 출하시기에 적 합한 개체를 채취하여 잔류량을 분석하였다. 포장별 초기 평균 잔류량은 mandipropamid $6.68-17.87 \mathrm{mg} / \mathrm{kg}$, thiamethoxam $4.96-$ $8.31 \mathrm{mg} / \mathrm{kg}$ 이었고 10 일 경과 후 각각 초기잔류량의 $16-54$ 및 $14-44 \%$ 수준으로 감소하였다. Thiamethoxam의 대사산물인 clothianidin은 $<0.02-0.37 \mathrm{mg} / \mathrm{kg}$ 으로 검출되었다. 상추 중 두 약제 의 잔류량은 단순 1 차 감쇄반응처럼 감소하였으며 포장구분없이 일자별 잔류량 회귀식을 산출한 결과, 평균 감소상수 및 생물학 적 반감기는 mandipropamid의 경우 -0.1060 및 6.5 일이었고 thiamethoxam은 -0.1236 및 5.6일이었다. 상추 잔류량 감소상수 의 $95 \%$ 신뢰구간 상한치는 mandipropamid -0.0746 및 thiamethoxam -0.1091 이었으며, 출하 10 일 및 5 일 전 PHRLs은 mandipropamid의 경우 63.24 및 $43.56 \mathrm{mg} / \mathrm{kg}$, thiamethoxam은 
44.66 및 $25.88 \mathrm{mg} / \mathrm{kg}$ 으로 산출되었다. 본 연구결과는 농가에 서 농작물 출하시기를 조절하는데 활용될 수 있으며 농가의 소 득 안정화에 기여할 것으로 판단된다.

Keywords 감소상수·생산단계 잔류허용기준·Mandipropamid· Thiamethoxam

감사의 글 본 연구는 2018 년도 식품의약품안전처의 연구개발비 (17162MFDS010)로 수행되었으며 이에 감사드립니다.

\section{References}

1. MAFRA (2019) 2018 status of greenhouse and production for vegetables. Ministry of Agriculture, Food and Rural Affairs, Sejong, Korea, pp 19-21

2. MAFRA (2019) Primary statistics of agriculture, food and rural affairs. Ministry of Agriculture, Food and Rural Affairs, Sejong, Korea, pp 74 77

3. NAQS (2020) Pesticide residue in agricultural products. National Agricultural Products Quality Management Service, Gimcheon, Korea

4. KCPA (2019) Guideline Crop Protection Agents. Korea Crop Protection Association, Seoul, Korea

5. Kim YS, Park JH, Park JW, Lee YD, Lee KS, Kim JE (2002) Persistence and dislodgeable residues of chlorpyrifos and procymidone in lettuce leaves under greenhouse condition. Korean J Environ Agric 21: 149-155

6. Marín A, Oliva J, Garcia C, Navarro S, Barba A (2003) Dissipation rates of cyprodinil and fludioxonil in lettuce and table grape in the field and under cold storage conditions. J Agric Food Chem 51: 4708-4711

7. MFDS (2020) Food Code. Ministry for Food and Drug Safety, Cheongju, Korea, pp 80-83, 655-657

8. Lee HR, Riu MJ, Park HW, Na YL, Song HH, Keum YS, Zhu Y, Kim JH (2009) Establishment of analytical method for fenhexamid residue in Korean cabbage, apple, mandarin and green pepper. Korean J Pestic Sci 13: $223-231$

9. OECD (2011) OECD MRL Calculator: User Guide. OECD Environment,
Health and Safety Publications Series on Pesticides No. 56. Organisation for Economic Cooperation and Development, Paris, France

10. MFDS (2014) OECD MRL Calculator: Statistical white paper. Ministry for Food and Drug Safety, Cheongju, Korea

11. Turner JA (2019) The Pesticide Manual. 18th edition, British Crop Production Council, UK, pp 235-236, 710-711, 1123-1124

12. MFDS (2014) Pre-harvest residue limits (PHRLs) manual. Ministry for Food and Drug Safety, Cheongju, Korea

13. Lee HD, Kyung KS, Kwon H, Ihm YB, Kim J, Park S, Kim J (2004) Residue characteristics of hexaconazole and chlorothalonil in several fruit. Korean J Pestic Sci 8: 107-111

14. Lee HD, Ihm YB, Kwon HY, Kim JB, Kyung KS, Park SS, Oh BY, Im GJ, Kim JE (2005) Characteristics of pesticide residue in/on cucurbitaceous fruit vegetables applied with foliar spraying under greenhouse. Korean J Pestic Sci 9: 359-364

15. Poulsen ME, Wenneker M, Withagen J, Christensen HB (2012) Pesticide residues in individual versus composite samples of apples after fine or coarse spray quality application. Crop Protect 35: 5-14

16. Choung MG, Ahn KG, Kim GP, Hwang YS, Kwon CH, Kang IK, Lee YD (2016) Dissipation pattern of a fungicide mandipropamid in Korean cabbage at different harvest times under greenhouse conditions. Korean J Hortic Sci Technol 34: 644-654

17. Lee EY, Kim DK, Park IY, Noh HH, Park YS, Kim TH, Jin CW, Kim KI, Yun SS, Oh SK, Kyung KS (2008) Residue patterns of indoxacarb and thiamethoxam in chinese cabbage (Brassica campestris L.) grown under greenhouse conditions and their estimated daily intake. Korean J Environ Agri 27: 92-98

18. Rahman MS (1999) Handbook of Food Preservation. Part IIConventional Food Preservation Methods, $\mathrm{pH}$ in Food Preservation. pp 384. Marcel Dekker, Inc. New York

19. Rahman M, Farha W, Abd EI-Aty AM, Kabir H, Im SJ, Jung DI, Choi JH, Kim SW, Son YW, Kwan CH, Shin HC, Shim JH (2015) Dynamic behavior and residual pattern of thiamethoxam and its metabolite clothianidin in swiss chard using liquid chromatography-tandem mass spectrometry. Food Chem 174: 248-255

20. Liu N, Pan X, Yang Q, Ji M, Zhang Z (2018) The dissipation of thiamethoxam and its main metabolite clothianidin during strawberry growth and jam-making process. Scientific Reports 8: 15242 